\title{
コンクリート二次製品工場において排出する セメントスラリーの再利用に関する研究
}

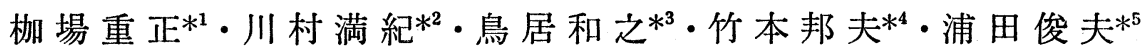

\section{1.まえがき}

コンクリート二次製品工場から排出されるセメントス ラリー（以下スラリーと呼ぶ）の適切な処理が問題とな っている。現在は環境公害防止の観点から，排出スラリ 一に対して, 薬液による中和および脱水等の処理を施し て廃棄しているのが実情である。しかし，一般に製品重 量に対して 4〜6\%（たとえば本実験で対象とした P C くい製造工場のスラリーの排出量は $15 \mathrm{t} /$ 日 であり，く い生産量の $5.5 \%$ にあたる）と多量に排出されるスラリ 一に対して今後廃棄場所等の確保が困難となる状況が予 想されることから, 従来のような廃棄処理方法が行き詰 まることが考えられ，排出スラリーの再利用を含む新た な処理方法等の抜本的な対策を講ずる必要性が生じてき ていると思われる。さらに，排出スラリーの再利用を検 討することは, 省資源および省エネルギーの立場からも 興味ある問題と思われる。

そこで本研究は，P C〈製造時に排出されるスラリ 一を非構造体用ブロック用コンクリート（たとえばコン クリートれんが, 支柱基礎ブロック, 法覆板等) の結合 材として再利用することを目的としたものである。

とくに本研究は, 排出されるスラリーのみを結合材と したコンクリートではスラリーの水セメント比が大きく 変動するので品質管理が困難であることから，他の産業 副産物である高炉スラグ粉末（以下スラグ粉末と呼ぶ） および脱硫石こう（以下石こうと呼ぶ）を併用し，アル カリ刺激剤として利用する可能性を検討したものであ る。

P C くい製造工場における排出スラリーは，セメン ト，水およびシルト等から成り，PCくい製造過程の遠 心力締固めの際, 各 P C くい中空部に残留するものであ

*1 正会員 金沢大学教授 工学部土木工学科

*2 正会員 金沢大学教授 複合材料応用研究センター

*3 正会員 金沢大学助手 工学部土木工学科

*4 正会員 金沢大学助手 複合材料応用研究センター

*5 北陸コンクリート工業 (株) 技術部長
る。この排出スラリーをコンクリート用結合材として再 利用する場合の一つの大きな問題点は, 排出されるスラ リーの水セメント比および石粉等の微粒子分が種々の要 因によって大きく変動することである。

そこでまず, 排出スラリーの水セメント比の変動の特 徵および原因について検討した。

つぎに，スラリーに石こうおよびスラグ粉末を加えて 結合材としたコンクリート（以下スラグ・石こうコンク リートと呼ぶ）を作成し，強度特性および示差熱分析， 走査型電子顕微鏡による内部組織の観察に基づいて水和 反応特性を明らかにすることによって，排出スラリーの 再利用に関する可能性を検討した（実験 I )。

排出スラリーを用いたスラグ・石こうコンクリート は, 結合材の配合割合が適切であれば十分な強度が得ら れることが明らかになった。しかし，スラグ・石こらユ ンクリートでは結合材の配合割合がコンクリートの品質 に及ぼす影響が大きいので, 水セメント比の変動の大き い排出スラリーを用いた場合，コンクリートの品質管理 がかなり難しいと考えられる。さらに，スラグ・石こう コンクリートでは使用セメント量が比較的少ないので多 量のスラリーを処理しなければならないという実情を考 えて, 排出スラリーをより多量に用いるスラグコンクリ 一トの結合材としてのスラリーの有効性について検討す ることは意義あることと思われる。そこで，コンクリー トの品質に大きく影響するスラリーの水セメント比の変 動を軽減するために, 連続して排出されるスラリーを擋 拌しながら貯留したスラリーとスラグ粉末とを結合材と したコンクリート（以下スラグコンクリートと呼ぶ）を 作成し, その強度特性, 乾燥収縮および耐久性を明らか にした (実験II)。

\section{2. 実験 概 要}

\section{1 スラリーの水セメント比の決定}

本研究に使用したスラリーは，P Cくい製造過程にお ける遠心力締固め終了時に採取したものである（P Cく 
表一1ＰCくいコンクリートの配合

\begin{tabular}{|c|c|c|c|c|c|c|c|c|}
\hline 最 & 水 & 細 & \multicolumn{6}{|c|}{ 単 位 量 $\left(\mathrm{kg} / \mathrm{m}^{3}\right)$} \\
\hline 大 & $x$ & 骨 & \multirow{3}{*}{$\begin{array}{l}セ \\
x \\
\nu \\
ト\end{array}$} & \multicolumn{2}{|c|}{$\mathrm{S}$} & \multicolumn{2}{|c|}{ G } & 混 \\
\hline 法 & $\underset{\text { 比 }}{r}$ & 怀 & & け & 川 & け & 砕 & 和 \\
\hline$(\mathrm{mm})$ & $(\%)$ & $(\%)$ & & 砂 & 砂 & 石 & 石 & 剂 \\
\hline 25 & 31.5 & 40 & 460 & 353 & 353 & 848 & 214 & 6.9 \\
\hline
\end{tabular}

い製造の際に用いられたコンクリートの材料および配合 は 表一1 に示すとおりである)。スラリーの水セメント 比の推定には, 排出スラリー中の石粉等の微粒子分の変 動が予想されたので, シルト分に影響されない方法とし て塩酸とセメントの反応熱による方法 ${ }^{1)}$ を採用した。ス ラリー中には石粉等の微粒子分, ほかに型わく油等の不 純物も含有している。

\section{2 スラグ・石こうコンクリートに関する実験（実 験 I )}

\section{(1) 強度試験}

打設したコンクリートの種類および配合は，スラリー の水セメント比を考慮して表一2のように決めた。

各種コンクリートの使用スラリー量は, 各結合材中の セメント量がスラリーに含まれるセメント分によって与 えられるように決定し, 各配合に対する単位氷量から使 用スラリー中の水量を差し引いた水量を練りまぜ水とし て加えた。各コンクリートは強制混合型ミキサ（容量 $50 l$ ) で練りまぜ, スランプ, 空気量および単位容積重 量を測定した後, 直径 $10 \mathrm{~cm}$, 高さ $20 \mathrm{~cm}$ の円柱型わ くに詰め, 所定期間 ( 7 日，28 日，90 日材令）水中養 生後, 圧縮および引張強度試験を行った。

使用したスラグ粉末は，市販の高炉スラグ粉末（S社 製) である。石こうは，北陸電力（株）から供給された 排煙脱硫石こう（二水石こう）であり，使用時の付着水 は $0.4 \%$ である。粗骨材は最大寸法 $25 \mathrm{~mm}$ の砕石（比 重 2.60 , 吸水率 $0.80 \%, F . M .=7.23$ ) であり, 細骨材 として川砂（比重 2.58 , 吸水率 $2.80 \%, F . M .=2.35$ ) を使用した。

\section{（2）示差熱分析（DTA）および 走 査 型 電子顕微鏡 (SEM) による}

DTA および SEM 観察に供した試料は, 表一2 に示 す各配合のペースト部分に相当するものである。DTA 用試料は, 所定期間水中養生された直径 $5 \mathrm{~cm}$, 高さ 10 $\mathrm{cm}$ のペース卜供試体を破壊して得られた試料断片を指 頭に感じなくなるまで乳鉢で粉砕したものである。示差 熱分析装置は, サーモフレックス（理学電機社製）であ る（昇温速度 $10^{\circ} \mathrm{K} / \mathrm{min}$, 標準試料 : $\alpha-\mathrm{Al}_{2} \mathrm{O}_{3}$ )。 $\mathrm{SEM}$ 観察用試料は, 破断片を真空乾燥した後, 破断面を炭素 および金で蒸着し観察した。

\section{3 スラグコンクリートの諸性質に関する実験（実}

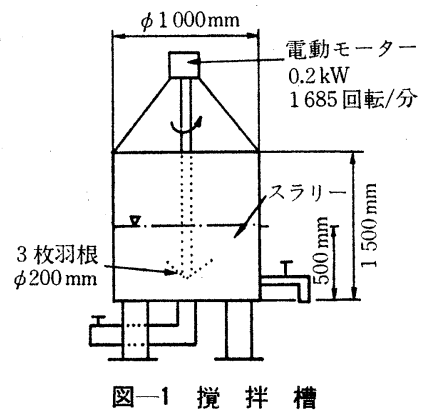

験 II)

採取したスラリーの水セメント比の変動がコンクリー トの品質に及ぼす影響を軽減するとともに，スラリーの 水セメント比の推定回数を減らすために, 図一1 に示す ような擋拌槽中で一定時間擋拌しながら貯留したスラリ 一をコンクリートの練りまぜに使用した。

作成したスラグコンクリートの種類および配合は表一 3 に示すとおりである。

使用したスラグ粉末は，実験Ｉ と同様に市販の高炉ス ラグ粉末である。粗骨材は, 最大寸法 $20 \mathrm{~mm}$ のけい石 （比重 2.58, 吸水率 $0.57 \%, F . M .=6.69$ ) であり, 細 骨材として川砂（比重 2.58, 吸水率 $2.80 \%, F . M .=$ 2.35）を使用した。

圧縮強度試験用供試体は直径 $10 \mathrm{~cm}$, 高さ $20 \mathrm{~cm}$ の円 柱体, 曲げ強度は $10 \times 10 \times 40 \mathrm{~cm}$ の角柱供試体を用い て三等分点載荷によって求めたものである。

乾燥収縮は， 2 週間水中養生 した $10 \times 10 \times 40 \mathrm{~cm}$ の 角柱供試体について, 温度 $20^{\circ} \mathrm{C}$, 相対湿度 $57 \%$ の恒温 恒湿室内においてコンパレータ法によって測定したもの である。

凍結融解試験は, 表一3 に示す $W / C=0.50$ および 0.55 の配合のコンクリートに対して作成した $10 \times 10 \times$ $40 \mathrm{~cm}$ の角柱供試体を 3 週間水中養生後, ASTM（水中 における急速凍結融解に対するコンクリート供試体の抵 抗試験方法）に従って行った。

耐硫酸塩試験は, 直径 $7.5 \mathrm{~cm}$, 高さ $15 \mathrm{~cm}$ の円柱供 試体に対してアメリカ開拓局の方法 ${ }^{2}$ に準じて実施し た。

\section{3. 実験結果および考察}

\section{1 採取スラリー中のセメント量および水量の変動}

図一2 は，コンクリート工場において 3 日間断続的に 採取したスラリー中の水セメント比の変動状況を示した ものである。この図から明らかなように，排出スラリー の水セメント比が大きく変動しているのがわかる。この


速度等によって生ずるものと思われる。たとえば 図一3 は, 締固め過程における高速回転時（締固め過程は低・ 
表一2 コンクリートの配合

\begin{tabular}{|c|c|c|c|c|c|c|c|c|c|}
\hline \multirow{2}{*}{ 結合材の種類と割合 } & \multirow{2}{*}{$\begin{array}{r}\text { 結合材量 } \\
\left(\mathrm{kg} / \mathrm{m}^{3}\right)\end{array}$} & \multirow{2}{*}{$\begin{array}{l}\text { 水 結 } \\
\text { 合 } \\
\text { 材 比 }\end{array}$} & \multirow{2}{*}{ 細骨材率 } & \multicolumn{6}{|c|}{ 単 位 量 $\left(\mathrm{kg} / \mathrm{m}^{3}\right)$} \\
\hline & & & & スラグ粉末 & 石こう & セメント & 水 量 & 細 骨 材 & 粗 骨材 \\
\hline \multirow{6}{*}{$\begin{array}{l}\text { スラグ粉末 : 石育 : セメン } \\
\text { ト } \\
\qquad 5: 13: 2\end{array}$} & \multirow{3}{*}{300} & 0.45 & \multirow{3}{*}{0.40} & \multirow{3}{*}{255} & \multirow{3}{*}{39} & \multirow{3}{*}{6} & \multirow{3}{*}{$\begin{array}{l}135 \\
165 \\
195\end{array}$} & 773 & 1168 \\
\hline & & 0.55 & & & & & & 743 & 1121 \\
\hline & & 0.65 & & & & & & 712 & 1074 \\
\hline & \multirow{3}{*}{350} & 0.45 & \multirow{3}{*}{$\begin{array}{l}0.40 \\
0.45\end{array}$} & \multirow{3}{*}{297.5} & \multirow{3}{*}{45.5} & \multirow{3}{*}{7} & \multirow{3}{*}{$\begin{array}{l}158 \\
193 \\
228 \\
\end{array}$} & 730 & 1105 \\
\hline & & 0.55 & & & & & & 781 & 962 \\
\hline & & 0.65 & & & & & & 741 & 913 \\
\hline \multirow{6}{*}{$85: 10: 5$} & & 0.45 & \multirow{3}{*}{0.45} & \multirow{3}{*}{255} & \multirow{3}{*}{30} & \multirow{3}{*}{15} & 135 & 871 & 1073 \\
\hline & 300 & 0.55 & & & & & 165 & 835 & 1029 \\
\hline & & 0.65 & & & & & 195 & 801 & 986 \\
\hline & \multirow{3}{*}{350} & 0.45 & \multirow{3}{*}{0.45} & \multirow{3}{*}{297.5} & \multirow{3}{*}{35} & \multirow{3}{*}{17.5} & 158 & 823 & 1014 \\
\hline & & 0.55 & & & & & 193 & 783 & 964 \\
\hline & & 0.65 & & & & & 228 & 742 & 913 \\
\hline \multirow{6}{*}{$85: 7: 8$} & & 0.45 & \multirow{3}{*}{0.45} & \multirow{3}{*}{255} & \multirow{3}{*}{21} & \multirow{3}{*}{24} & 135 & 871 & 1073 \\
\hline & 300 & 0.55 & & & & & 165 & 836 & 1030 \\
\hline & & 0.65 & & & & & 195 & 801 & 986 \\
\hline & \multirow{3}{*}{350} & 0.45 & & & & & 158 & 824 & 1016 \\
\hline & & 0.55 & 0.45 & 297.5 & 24.5 & 28 & 193 & 784 & 966 \\
\hline & & 0.65 & & & & & 228 & 743 & 915 \\
\hline
\end{tabular}

\begin{tabular}{|c|c|c|c|c|c|c|c|c|}
\hline \multirow{2}{*}{ 結合材の種類と割合 } & \multirow{2}{*}{$\begin{array}{l}\text { 給合材量 } \\
\left(\mathrm{kg} / \mathrm{m}^{3}\right)\end{array}$} & \multirow{2}{*}{ 水結合材比 } & \multirow{2}{*}{ 細骨材率 } & \multicolumn{5}{|c|}{ 单 位 量 $\left(\mathrm{kg} / \mathrm{m}^{8}\right)$} \\
\hline & & & & スラグ粉末 & セメント & 水 量 & 細 骨 材 & 粗骨材 \\
\hline \multirow{8}{*}{$\begin{array}{c}\text { スラグ粉末 : セメント } \\
50: 50\end{array}$} & \multirow{4}{*}{300} & 0.50 & \multirow{4}{*}{0.45} & \multirow{4}{*}{150} & \multirow{4}{*}{150} & \multirow{4}{*}{$\begin{array}{l}150 \\
165 \\
180 \\
195\end{array}$} & 860 & 1059 \\
\hline & & 0.55 & & & & & 843 & 1038 \\
\hline & & 0.60 & & & & & 825 & 1016 \\
\hline & & 0.65 & & & & & 808 & 995 \\
\hline & \multirow{4}{*}{350} & 0.50 & \multirow{4}{*}{0.45} & \multirow{4}{*}{175} & \multirow{4}{*}{175} & 175 & 812 & 1000 \\
\hline & & 0.55 & & & & 192.5 & 792 & 975 \\
\hline & & 0.60 & & & & 210 & 771 & 942 \\
\hline & & 0.65 & & & & 227.5 & 751 & 925 \\
\hline \multirow{8}{*}{$60: 40$} & \multirow{4}{*}{300} & 0.50 & \multirow{4}{*}{0.45} & \multirow{4}{*}{180} & \multirow{4}{*}{120} & 150 & 859 & 1058 \\
\hline & & 0.55 & & & & 165 & 842 & 1037 \\
\hline & & 0.60 & & & & 180 & 824 & 1015 \\
\hline & & 0.65 & & & & 195 & 807 & 994 \\
\hline & \multirow{4}{*}{350} & 0.50 & \multirow{4}{*}{0.45} & \multirow{4}{*}{210} & \multirow{4}{*}{140} & 175 & 811 & 998 \\
\hline & & 0.55 & & & & 192.5 & 790 & 973 \\
\hline & & 0.60 & & & & 210 & 770 & 948 \\
\hline & & 0.65 & & & & 227.5 & 750 & 923 \\
\hline \multirow{8}{*}{$70: 30$} & \multirow{4}{*}{300} & 0.50 & \multirow{4}{*}{0.45} & \multirow{4}{*}{210} & \multirow{4}{*}{90} & 150 & 858 & 1057 \\
\hline & & 0.55 & & & & 165 & 840 & 1035 \\
\hline & & 0.60 & & & & 180 & 823 & 1014 \\
\hline & & 0.65 & & & & 195 & 806 & 992 \\
\hline & \multirow{4}{*}{350} & 0.50 & \multirow{4}{*}{0.45} & \multirow{4}{*}{245} & & 175 & 809 & 997 \\
\hline & & 0.55 & & & 105 & 192.5 & 789 & 972 \\
\hline & & 0.60 & & & 200 & 210 & 769 & 947 \\
\hline & & 0.65 & & & & 227.5 & 748 & 922 \\
\hline
\end{tabular}


表一3 コンクリートの配合

\begin{tabular}{|c|c|c|c|c|c|c|c|c|}
\hline \multirow{2}{*}{ 結合材の種類と割合 } & \multirow{2}{*}{$\begin{array}{l}\text { 結合材量 } \\
\left(\mathrm{kg} / \mathrm{m}^{3}\right)\end{array}$} & \multirow{2}{*}{$\begin{array}{l}\text { 水セメント } \\
\text { 比 }\end{array}$} & \multirow{2}{*}{ 細骨材率 } & \multicolumn{5}{|c|}{ 単 位 量 $\left(\mathrm{kg} / \mathrm{m}^{3}\right)$} \\
\hline & & & & スラグ粉末 & セメント & 水 量 & 細 骨 材 & 粗骨材 \\
\hline \multirow{6}{*}{$\begin{array}{c}\text { スラグ粉末 : セメント } \\
30: 70\end{array}$} & \multirow{3}{*}{300} & 0.50 & \multirow{3}{*}{0.45} & \multirow{3}{*}{90} & \multirow{3}{*}{210} & 150 & 815 & 998 \\
\hline & & 0.55 & & & & 165 & 800 & 975 \\
\hline & & 0.60 & & & & 180 & 777 & 949 \\
\hline & \multirow{3}{*}{350} & 0.50 & \multirow{3}{*}{0.45} & \multirow{3}{*}{105} & \multirow{3}{*}{245} & 175 & 769 & 939 \\
\hline & & 0.55 & & & & 192.5 & 748 & 915 \\
\hline & & 0.60 & & & & 210 & 722 & 883 \\
\hline \multirow{6}{*}{$40: 60$} & \multirow{3}{*}{300} & 0.50 & \multirow{3}{*}{0.45} & \multirow{3}{*}{120} & \multirow{3}{*}{180} & 150 & 813 & 996 \\
\hline & & 0.55 & & & & 165 & 797 & 973 \\
\hline & & 0.60 & & & & 180 & 778 & 951 \\
\hline & \multirow{3}{*}{350} & 0.50 & \multirow{3}{*}{0.45} & \multirow{3}{*}{140} & \multirow{3}{*}{210} & 175 & 766 & 939 \\
\hline & & 0.55 & & & & 192.5 & 748 & 913 \\
\hline & & 0.60 & & & & 210 & 723 & 884 \\
\hline \multirow{6}{*}{$50: 50$} & \multirow{3}{*}{300} & 0.50 & \multirow{3}{*}{0.45} & \multirow{3}{*}{150} & \multirow{3}{*}{150} & 150 & 813 & 996 \\
\hline & & 0.55 & & & & 165 & 797 & 973 \\
\hline & & 0.60 & & & & 180 & 785 & 959 \\
\hline & \multirow{3}{*}{350} & 0.50 & \multirow{3}{*}{0.45} & \multirow{3}{*}{175} & & 175 & 766 & 934 \\
\hline & & 0.55 & & & 175 & 192.5 & 746 & 911 \\
\hline & & 0.60 & & & & 210 & 724 & 885 \\
\hline & & 0.50 & & & & 150 & 813 & 993 \\
\hline & 300 & 0.55 & 0.45 & 180 & 120 & 165 & 795 & 973 \\
\hline $60: 40$ & & 0.60 & & & & 180 & 779 & 952 \\
\hline 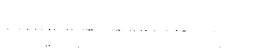 & & 0.50 & & & & 175 & 764 & 934 \\
\hline & 350 & 0.55 & $\therefore 0.45$ & 210 & 140 & 192.5 & 743 & 911 \\
\hline & & 0.60 & & & & 210 & 722 & 885 \\
\hline $0: 100$ & 350 & 0.50 & 0.45 & - & 350 & 175 & 731 & 894 \\
\hline
\end{tabular}

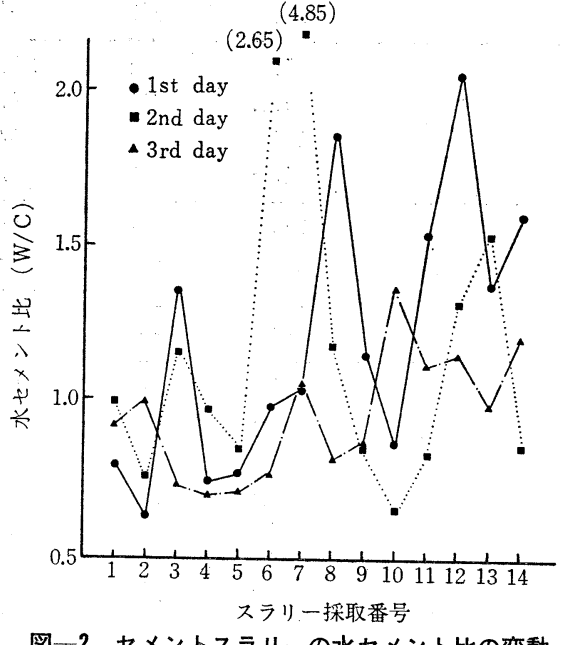

図一2 セメントスラリーの水セメント比の変動

中・高速回転の三段階よりなっている) の回転エネルギ ーとスラリー $1 \mathrm{~kg}$ 中のセメント量の関係を示してい る。この図より，各くい径ごとに回転エネルギーとセメ ント量との間には相関があり, 各くい径とも, エネルギ 一量が大きくなるにつれてスラリー中のセメント量が少

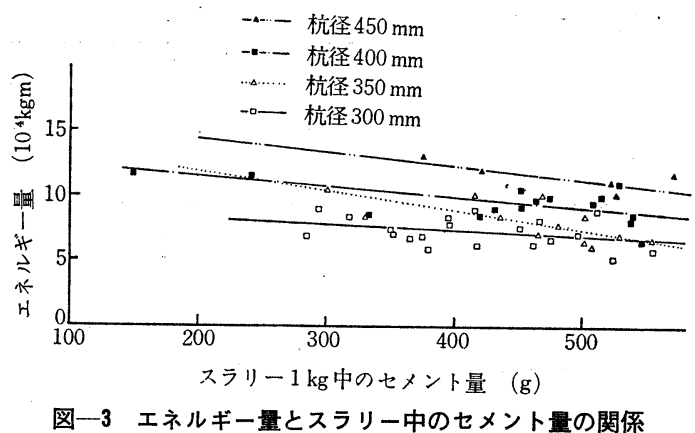

なくなっていることがわかる。これは，回転エネルギー 量が増加するにつれてコンクリートが十分締め固めら れ，〈い内部に残留するセメント量が減少することによ ると思われる。

採取したスラリーのみを使用して作成したコンクリー トの圧縮強度と水セメント比の関係を示すと図一4のよ らである。排出されるスラリーの水セメント比が $70 \%$ 程度より小さければ，ある程度の強度は期待できる。し かし図一2に示されるように，排出されるスラリーの水 セメント比は概して 70\% 程度より大きく, しかも変動 


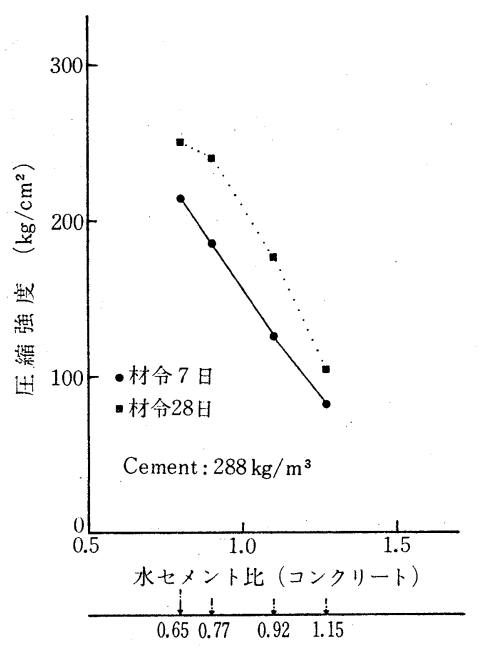

図一4 セメントスラリーを使用したコ ンクリートの圧縮強度と水セメ ント比の関係

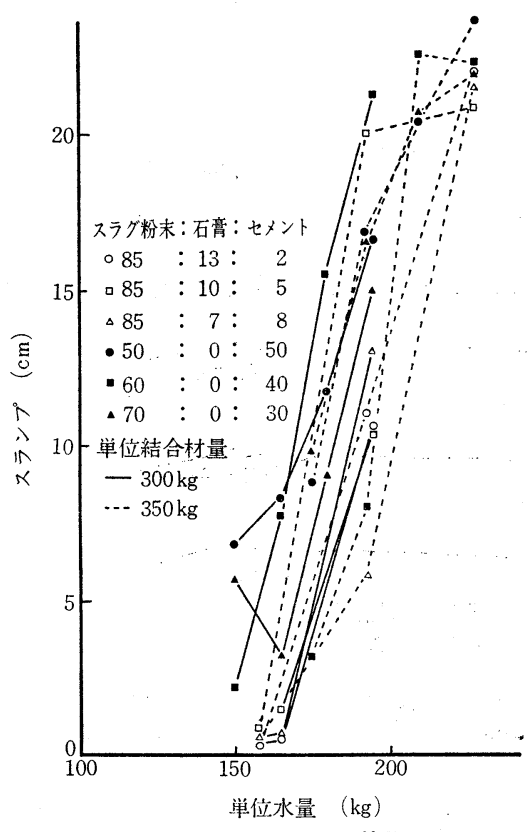

図一5 セメントスラリーを使用したコ ンクリートのスランプと単位水 量の関係

が大きいので，スラリーのみをそのまきコンクリート用 結合材として再利用することは不可能なようである。

\section{2 スラグコンクリートおよびスラグ · 石こうコン} クリートの諸性質 (実験 I )

（1）まだ固まらないコンクリートの性質

図一5 は，各種コンクリートのスランプと単位水量の 関係を示したものである。石こうを含む結合材を用いた コンクリートは, 一定の単位水量において, 石こうを含 まない結合材を用いたコンクリートよりす小さいスラン プを示す傾向がある。しかし, 通常のセメントコンクリ
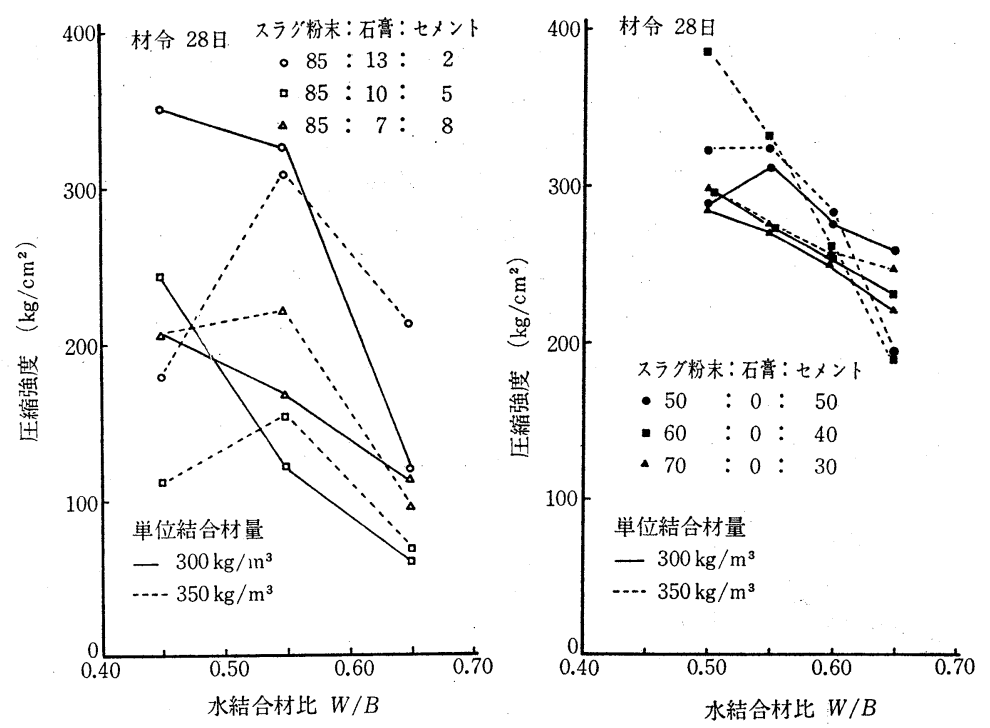

図一6 圧縮強度と水結合材比の関係
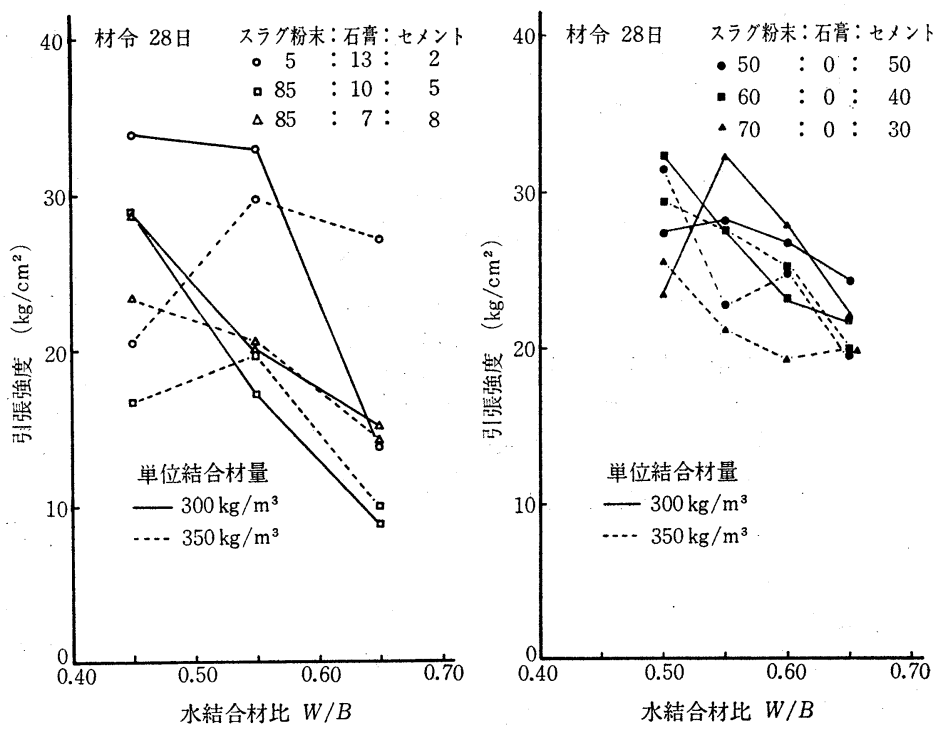

図一7 引張強度と水結合材比の関係

ートと同様に排出スラリーを用いたコンクリートにおい ても，ワーカブルな範囲ではスランプは単位水量と直線 関係にあることがわかる。

空気量は，ほとんどのコンクリートで $1 \%$ 前後の值を 示した。

\section{（2）硬化コンクリートの強度特性}

図一6 および図一7 は，材令 4 週における圧縮および 引張強度と水結合材比の関係を示す。図一6 に示すよう に, 石こうを含む場合は単位結合材量 $300 \mathrm{~kg} / \mathrm{m}^{3}$ におい て, 圧縮強度は水結合材比の増加とともにほぼ直線的に 低下する。

しかし，単位結合材量 $350 \mathrm{~kg} / \mathrm{m}^{3}$ のコンクリートの強 度は水結合材比が 0.55 で最大值を示す。また, 結合材 の混合割合がスラグ粉末 : 石こう: セメント =85:13: 
2 の場合, 水結合材比が 0.65 と高くなると単位結合材 量の多い $350 \mathrm{~kg} / \mathrm{m}^{3}$ が $300 \mathrm{~kg} / \mathrm{m}^{3}$ より大きい強度を示 す。この点は, 魚本・小林ら ${ }^{3)}$ が同様のスラグ・石こう コンクリートに関して得た実験結果（同一水結合材比で は単位結合材量の大きいものほど強度が小さい）と異な っているようである。これは, 本実験では, アルカリ刺 激凨として普通ポルトランドセメントではなく, $\mathrm{PC}<$ い製造工場から排出したセメントスラリーを用いたこと によるものと思われる。

スラグコンクリートにおいては, 各配合とも本研究に

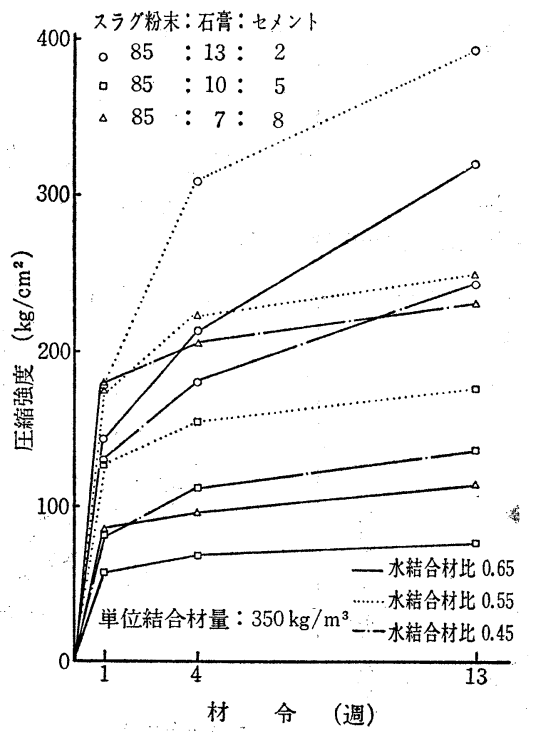

図一，压縮強度と材令の関係

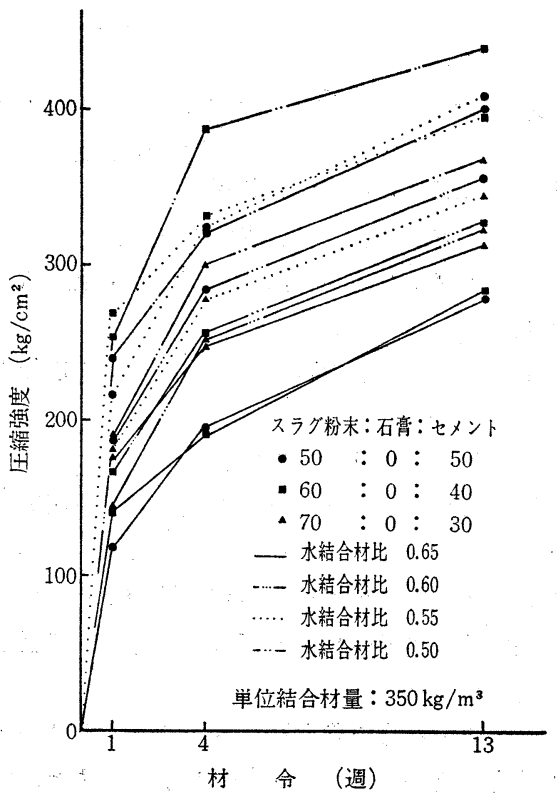

図一9 圧縮強度と材令の関係
おいて行った水結合材比の範囲内では, 圧縮強度は水結 合材比とほぼ直線関係にあることがわかる。

スラグ・石こうコンクリートの引張強度と水結合材比 の関係は, 図一7より明らかなように, ほとんど圧縮強 度の場合と同様である。圧縮強度と引張強度の比は, 普 通コンクリートの場合とほぼ同じ程度である。

図一8 および図一9は, 各種コンクリートにおける材 令と圧縮強度の関係を示したものである。これらの図よ
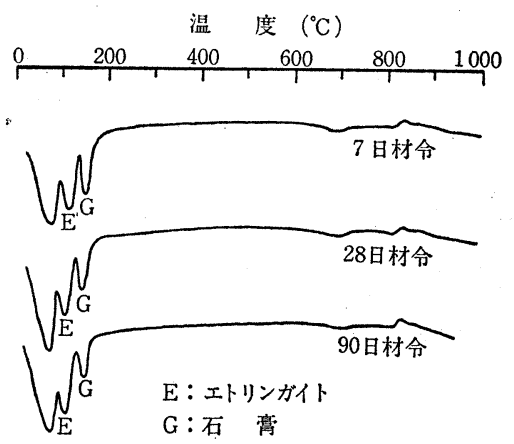

図一10 スラグ粉末:石こう：セメント=85:13:2, 水結合材比 0.35 のセメントペーストの DTA 曲線
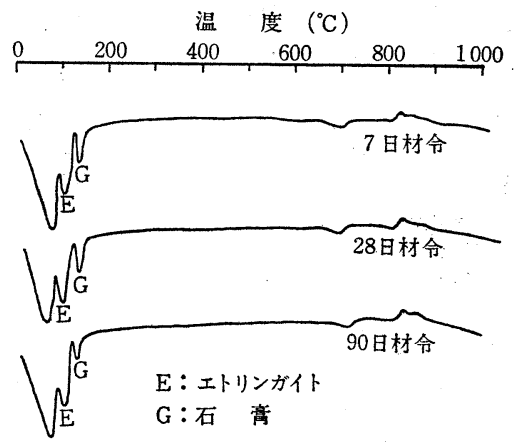

図一11 スラグ粉末 : 石こう：セメント =85:13:2, 水結合材比 0.45 のセメントペーストの DTA 曲線

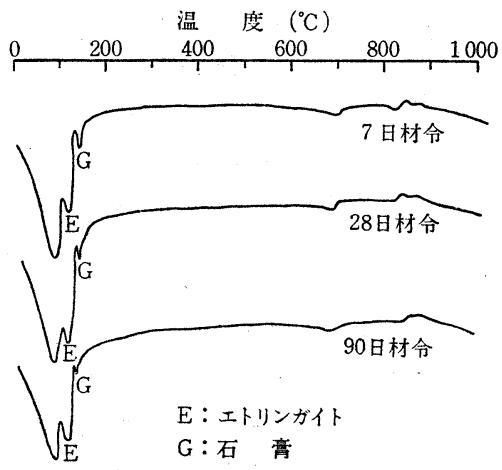

図-12 スラグ粉末 : 石こう : セメント =85:13:2, 水結合材比 0.55 のセメントペーストの DTA 曲線 


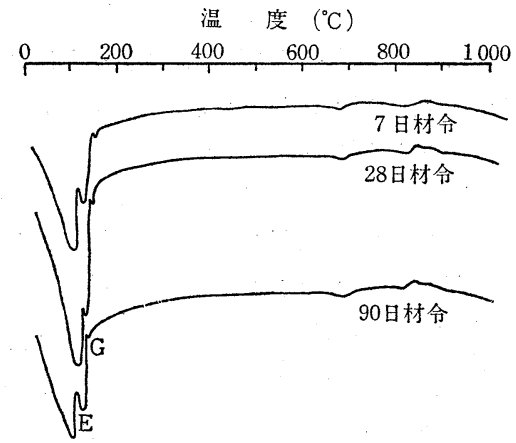

図一13 スラグ粉末 : 石こう：セメント $=85: 13: 2$, 水結合材比 0.65 のセメントペーストのDTA 曲線 (E：エトリンガイト, $\mathrm{G}$ : 石こう)

り，石こうを含む場合は，結合材の混合割合がスラグ粉 末:石こう：セメント $=85: 13: 2$ の場合に強度の伸び が大きいようである。しかし，石こうを含まないスラグ コンクリートにおいては, 結合材の混合割合の間で強度 の伸び率に大きな差はないようである。

\section{(3) 示差熱分析}

図一10〜図一13 は,結合材の混合割合がスラグ粉末： 石こう: セメント $=85: 13: 2$ の水結 合材比が 0.35 , $0.45,0.55$ 㧍よび 0.65 の各配合に対する硬化結合材 の各材令に扔ける DTA 曲線である。これらの DTA 曲線には，エトリンガイトの吸熱ピークが認められる。 しかし, この吸熱ピークの高さの材令に伴ら変化は顕著 ではない。

一方, 石こうの吸熱ピークについては, 水結合材比が 0.35 に扔いては材令に伴う石こうの吸熱ピークの変化 はほとんどみられないが, 水結合材比が 0.45 以上では 石こうの吸熱ピークは材令とともに減少し, その減少の 度合いは水結合材比が小さいほど著しい。このことは, 水結合材比が 0.35 においては，石こうを消費するよう な反応が他のものに比べて活発でないことを示してい る。魚本・小林ら ${ }^{4}$ は X 線回折によって同様な結果を得 ている。

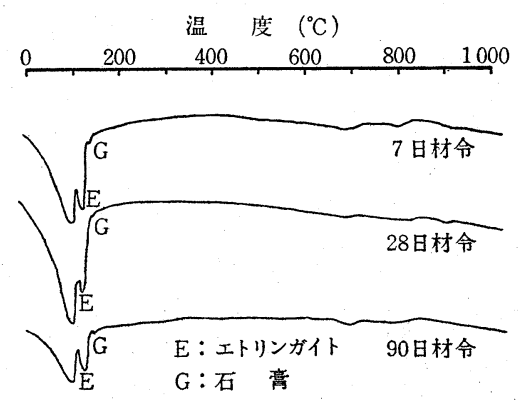

図一14 スラグ粉末：石こう：セメント $=85: 7: 8$; 水 結合材比 0.45 のセメントペーストの DTA 曲線
図一14 および図一15 は, スラグ粉末:石こう：セメ ント $=85: 10: 5$ および $85: 7: 8$ (水結合材比 0.45 ) に対する DTA 曲線を示している。いずれの混合割合 においてもエトリンガイトの吸熱ピークが認められ, 石 こうの吸熱ピーク高さも材令とともに減少しているが, その変化はスラグ粉末 : 石こう : セメント $=85: 13: 2$ の場合ほど明確ではない（図一11)。

図一16 および 図一17 は，スラリー硬化体抢よびスラ リー・スラグ粉末硬化体 (スラグ粉末 : セメント $=50$ : 50 , 水結合材比 0.55$)$ に対する DTA 曲線を示してい る。両者ともに大きな水酸化カルシウムの吸熱ピーク (約 $460^{\circ} \mathrm{C}$ ) が認められる。スラリー硬化体では, 長期 材令に㧍いても水酸化カルシウムのピークの大きさには



図一15 スラグ粉末: 石こう：セメント=85:10:5, 水結合材比 0.45 のセメントペーストの DTA 曲線

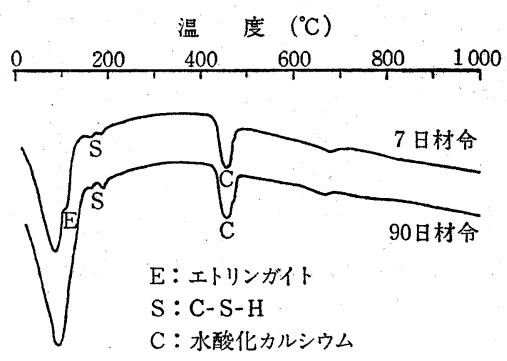

図一16 セメントスラリー硬化体の DTA 曲線
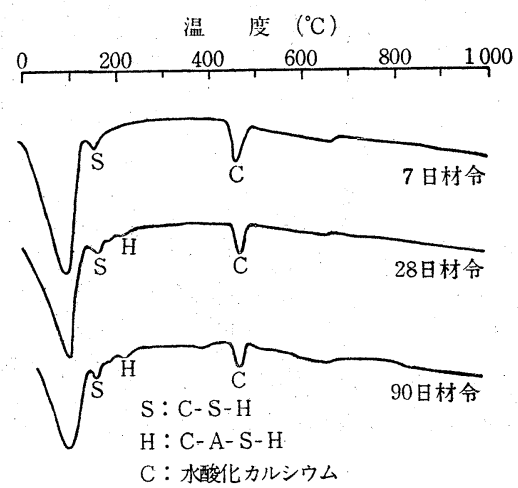

図一17 スラグ粉末：セメント $=50: 50$, 水結合材比 0.55 のセメントペーストの DTA 曲線 
ほとんど変化がない。しかし，スラグ粉末を含む硬化ぺ ーストの DTA 曲線における水酸化カルシウムのピー クは材令とともに小さくなっている。さらに, スラリー ・スラグ粉末硬化体の DTA 曲線には C-S-H および $\mathrm{C}-\mathrm{A}-\mathrm{S}-\mathrm{H}$ 系の吸熱ピークがスラリー硬化体の DTA 曲線よりも顕著に認められることから，スラリーのアル カリ刺激によりスラグ粉末の潜在水硬性が発揮されてい ることがわかる。

\section{(4) 走査型電子顕微鏡による観察}

写真-1 4 は,スラグ粉末 : 石こう : セメント = 85 : $13: 2$, 水結合材比 $0.35,0.45,0.55$ および 0.65 の各 SEM 像を示す。強度発現の良好な混合割合に相当する 硬化結合材においては，エトリンガイトの針状結晶の生 成が著しいことがわかる（写真一2 および写真一3）。さ らに写真一5のように，針状結晶は比較的大きな石こう 粒子付近に多数存在していることがわかる。一方, 石こ 5粒子の表面は，写真一6 および 写真一8 に示すように 水和反応の進行とともに溶解して大きく変化しているこ とがわかる。写真一6 に示される粒子が石こうであるこ とは, 写真一6 における黒丸印を付した部分を EPMA

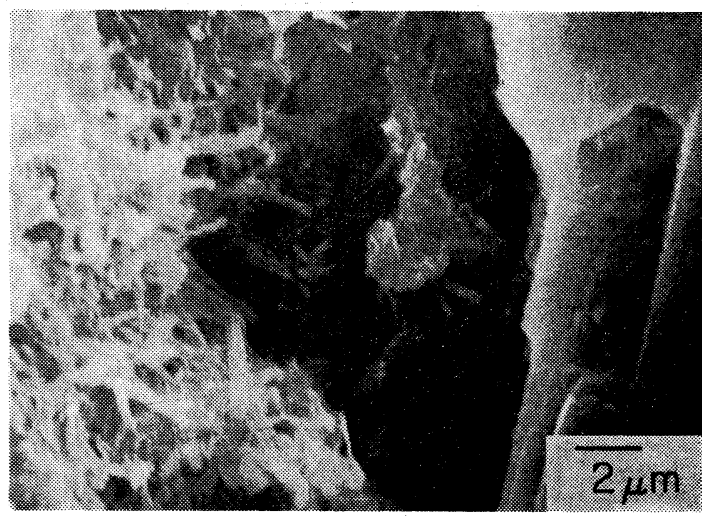

写真一1 セメントスラリーを使用したセメントペーストの 破面の SEM 像(スラグ粉末 : 石こう : セメント $=85: 13: 2$, 水結合材比 0.35 , 材令 7 日)

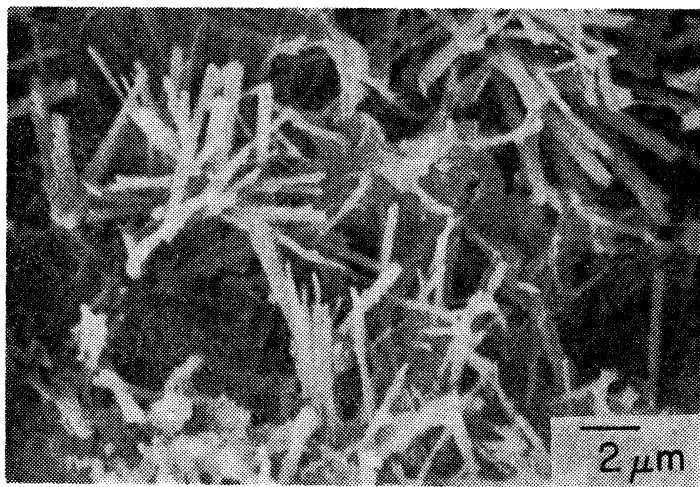

写真一2 セメントスラリーを使用したセメントペーストの 破面の SEM 像(スラグ粉末 : 石こう：セメント $=85: 13: 2$, 水結合材比 0.45 , 材令 7 日)
によって分析した結果の写真一7により明らかである。

このように, スラグ・石こうコンクリートにおいては 石こう粒子の溶解に伴って，その周囲にエトリンガイト の針状結晶が生成されるようである。

写真一9 は, スラグ粉末 : 石こ5：セメント=85:10 $: 5$, 水結合材比 0.45 に対する SEM 像である。写真 -2 および 写真一9 を比較すると, 結合材中の石こうの

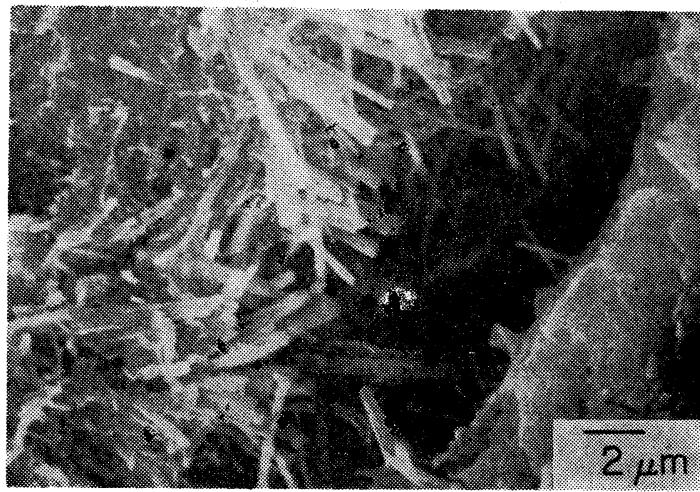

写真一3 セメントスラリーを使用したセメントペーストの 破面の SEM 像（スラグ粉末 : 石こう : セメン $卜=85: 13: 2$, 水結合材比 0.55 , 材令 7 日)

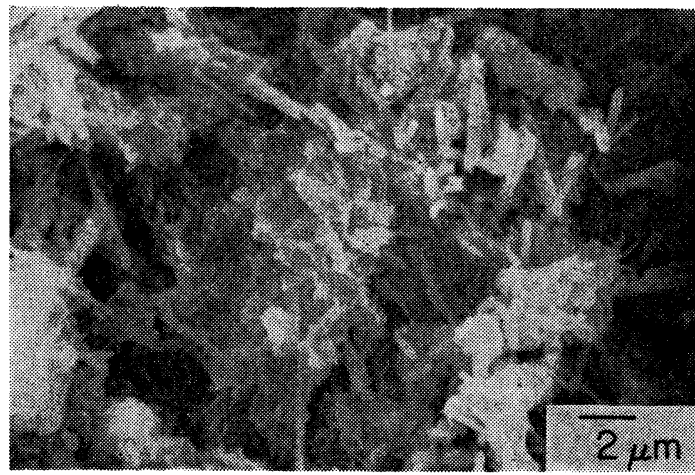

写真一4 セメントスラリーを使用したセメントペーストの 破面の SEM 像（スラグ粉末 : 石こう：セメン $卜=85: 13: 2$, 水結合材比 0.65 , 材令 7 日)

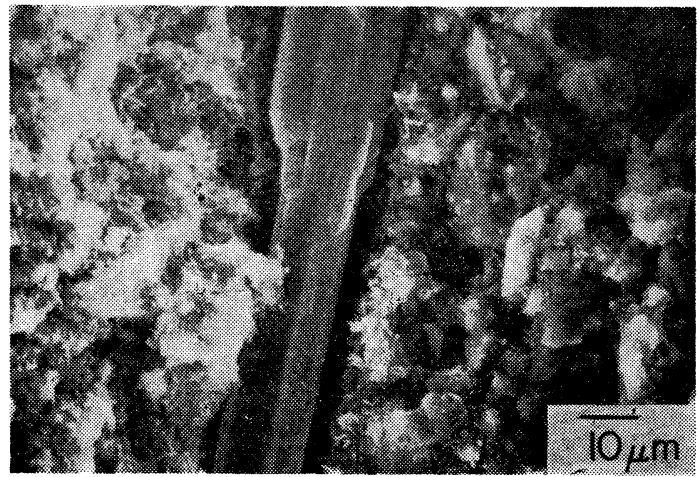

写真一5 セメントスラリーを使用したセメントペーストの 破面の SEM 像（スラグ粉末: 石こう：セメン $ト=85: 13: 2$, 水結合材比 0.35 , 材令 7 日） 
割合の相違によってエトリンガイトの針状結晶の大きさ が著しく異なっていることがわかる。このように，生成 されるエトリンガイトの結晶形態の相違が，スラグ・石

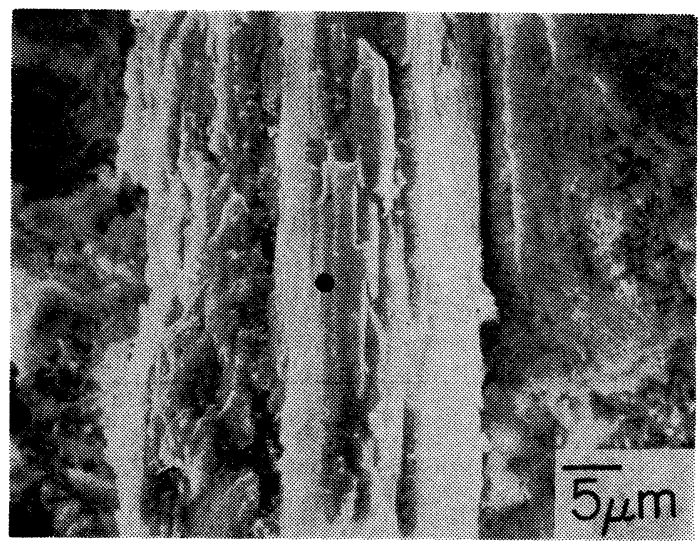

写真一6 セメントスラリーを使用したセメントペーストの 破面の SEM 像(スラグ粉末 : 石こう：セメント $=85: 13: 2$, 水結合材比 0.35 , 材令 7 日)

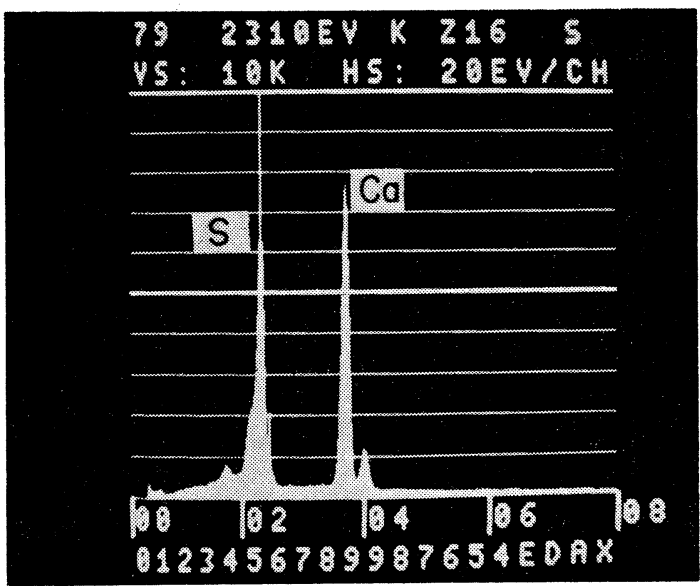

写真一7 セメントスラリーを使用したセメントペーストの 破面のX線マイクロアナリシス（写真一6に括け る黒丸印の部分）

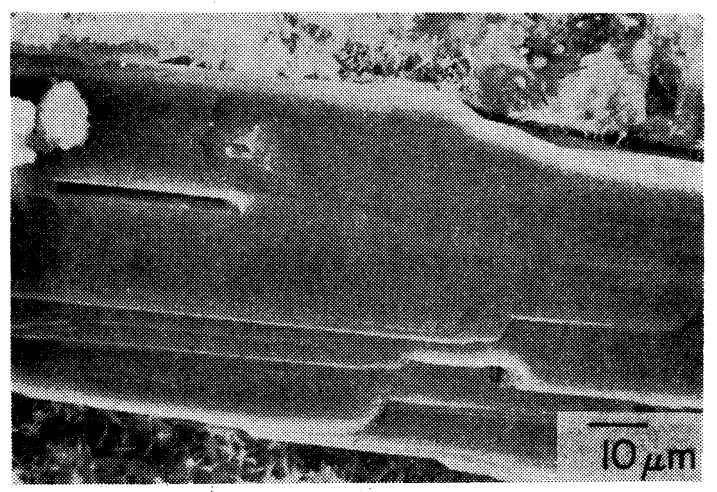

写真-8 セメントスラリーを使用したセメントペーストの 破面の SEM 像(スラグ粉末：不こう：セメント $=85: 13: 12$, 水結合材比 0.45 , 材令 7 日)
こうコンクリートにおける各結合材の混合割合による比 較的大きな強度差の一因であると考えられる。

結合材がスラグ粉末とスラリーのみで構成されている 場合には, 写真一10および 写真一11 に示すように, 水 酸化カルシウムの結晶抒よび針状の C-S-H 生成物が認 められる。

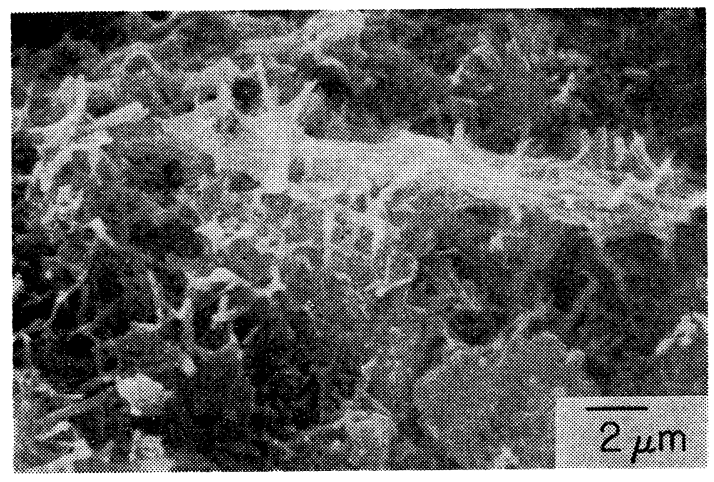

写真一9 セメントスラリーを使用したセメントペーストの 破面の SEM 像(スラグ粉末:石こう：セメント $=85: 10: 5$, 水結合材比 0.45 , 材令 7 日)

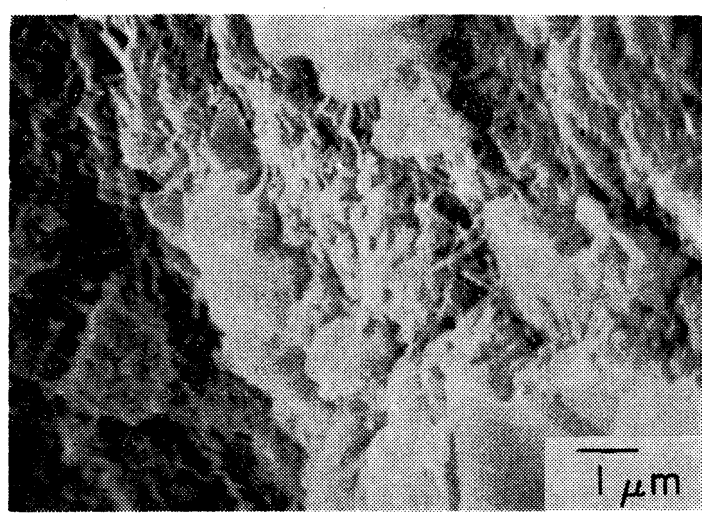

写真一10 セメントスラリーを使用したセメントペースト の破面の SEM 像（スラグ粉末 : セメント= $50: 50$, 水結合材比 0.55 , 材令 7 日)

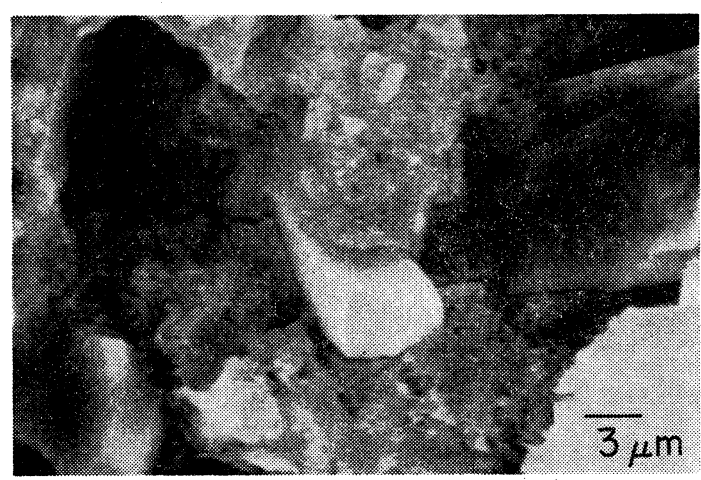

写真一11 セメントスラリーを使用したセメントペースト の破面の SEM 像（スラグ粉末：セハント= $60: 40$, 水絬合材比 0.55 , 材令 7 日) 
表一4 強度試験

\begin{tabular}{|c|c|c|c|c|c|}
\hline \multirow{2}{*}{$\frac{\text { No. }}{\mathrm{a}}$} & \multicolumn{3}{|c|}{ 王 縮 強 度: } & 平. 均 & 変動係数 \\
\hline & 243 & 207 & 218 & 223 & 6.8 \\
\hline b & 142 & 137 & 161 & 147 & 7.0 \\
\hline $\mathrm{c}$ & 179 & 168 & 168 & 172 & 3.0 \\
\hline $\mathrm{d}$ & 161 & 146 & 152 & 153 & 4.0 \\
\hline $\mathrm{e}$ & 190 & 190 & 191 & 190 & 0.3 \\
\hline f & 155 & 152 & 163 & 157 & 3.0 \\
\hline g & 123 & 124 & 130 & 126 & 2.5 \\
\hline $\mathrm{h}$ & 195 & 227 & 241 & 221 & 8.7 \\
\hline 全 & & & & $\mathrm{kg} / \mathrm{cm}^{2}$ & \\
\hline バ & 間 & 你 & & $9 \%$ & \\
\hline
\end{tabular}

表一5 分散分析

\begin{tabular}{c|r|r|r|r|r|r}
\hline 因子 & ss & $\mathrm{r}$ & $\mathrm{ms}$ & $\mathrm{F}$ & $\mathrm{F}_{0.05}$ & $\rho(\%)$ \\
\hline 級 閒 & 26000 & 7 & 3720 & 25 & 2.68 & 88 \\
級 内 & 2400 & 16 & 150 & - & - & 12 \\
\hline 計 & 28400 & 23 & - & - & - & 100 \\
\hline
\end{tabular}

スラリーの水セメント比を推定しながら, そのスラリ 一を用いたコンクリートを製造する場合, コンクリート の品質のばらつきが大きな問題となると思われるので, スラグ・石こらコンクリートを作製することによって, バッチ間の圧縮強度の変動について検討した。 8 種類の 採取スラリーに対して目標配合（スラグ粉末 : 石こう： セメント $=85: 7: 8$, 単位結合材量 $350 \mathrm{~kg} / \mathrm{m}^{3}$, 水結合 材比 0.55）のコンクリートの材令 4 週における圧縮強 度の変動の程度を示すと 表一4 のようである。表一5 は, 分散分析によってバッチ間の有意差検定を行った結 果を示したものである。明らかにバッチ間には有意差が 存在する。この結果より, 異なったスラリーを連続的に 使用して製造されたスラグ・石こらコンクリートの強度 の変動係数は, 通常のコンクリートの場合よりかなり大 きくなることがわかった。

\section{3 擋拌しながら貯留したスラリーを使用したスラ} グコンクリートの諸性質

(1) 擋拌・貯留によるスラリーの水セメント比の変 動低減効果

本実験では，コンクリートの品質に影響するスラリー の水セメント比の変動を軽減するために, スラリーを擋 拌しながら貯留する方法を採用した。

図一18は，PCくいの製造過程において引き続き採 取したスラリーの水セメント比の変動を示す。図一18 に打ける擋拌しない場合の值は図一2から引用したもの である。この図より, 引き続き排出されるスラリーを擋 拌しながら貯留すると各ロット間の水セメント比の変動 が小さくなっていることがわかる。これは, 引き続き排 出されたスラリーを混合するので水セメント比の変動が

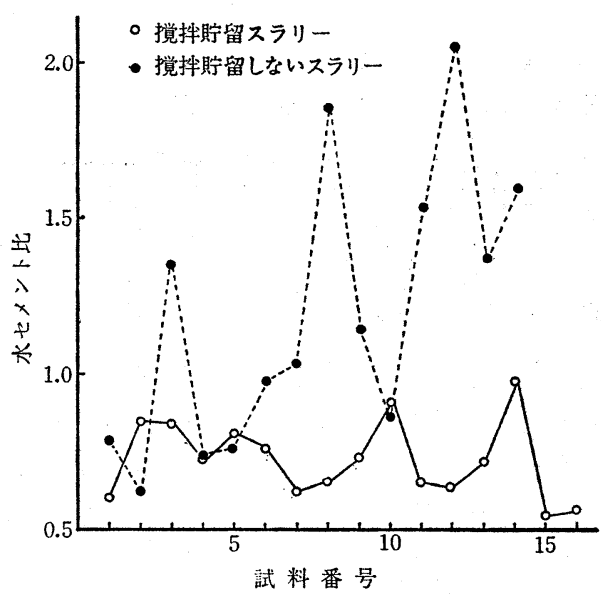

図一18 セメントスラリーの水セメント比の変動

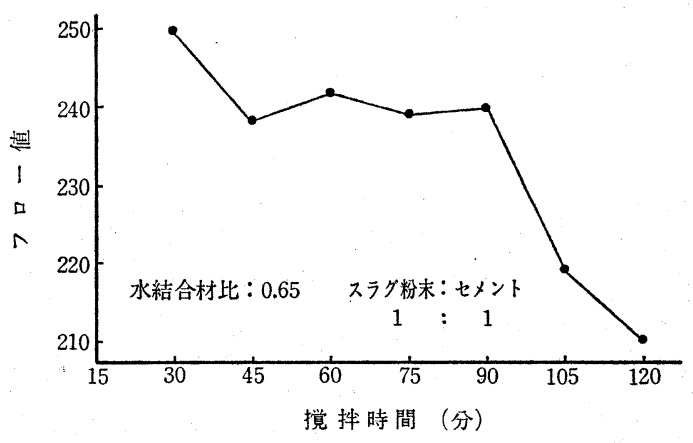

図一19 セメントスラリーを使用したモルタルのフロ 一値の経時変化

緩和されるためと思われる。結局, 擋拌しながらスラリ 一を貯留することは有効であることが示されているもの と思われる。

\section{（2）貯留時間がモルタルのコンシステンシーに及ぼ す影響}

擋拌しながら貯留したスラリーを使用する場合, 貯留 時間が長くなるとコンクリートのワーカビリチーが悪く なると考えられるので，スラリーの使用時間が制限され ると思われる。

図一19 は, 貯留時間に伴らスラグモルタルのフロー 值の変化を示す。図一19より, 擋拌時間が 90 分程度ま ではモルタルのコンシステンシーがほとんど変化しない ことがわかる。

\section{（3）スラグコンクリートの諸性質}

\section{（a）まだ固まらないコンクリートの性質}

表一6 に示すように, 擋拌・貯留したスラリーを用い たスラグコンクリートでは, 結合材の種類および配合に かかわらず多量の空気が連行される。 PCくい製造時に 用いられている混和剤 (表一1) は高性能減水剤であり, 練上り時の空気量が $2 \%$ 程度であることおよび擋拌・貯 留しないスラリーを用いたコンクリートでは多量の空気 
が連行されないことから, 表一6 に示されるような多量 の空気は擋拌によって連行されたものと思われる。

（b） スラグコンクリートの強度特性

表一6 各コンクリートの空気量

\begin{tabular}{c|c|c|c}
\hline 絬合材の種類と制合 & $\begin{array}{c}\text { 結合材量 } \\
\left(\mathrm{kg} / \mathrm{m}^{3}\right)\end{array}$ & $\begin{array}{c}\text { 水結合材 } \\
\text { 比 }\end{array}$ & $\begin{array}{c}\text { 空 気 } \\
(\%)\end{array}$ \\
\hline \multirow{3}{*}{ スラグ量 } \\
30
\end{tabular}

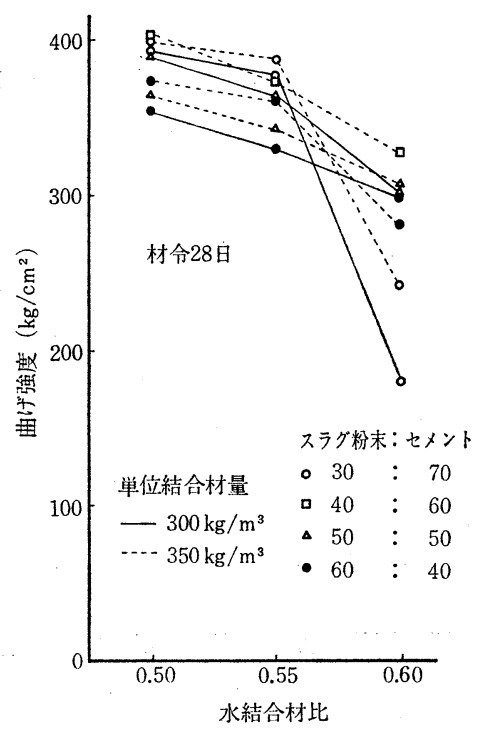

図一20 圧縮強度と水結合材比の関係
図一20 は, 材令 4 週に扔ける圧縮強度 と水結合材比 の関係を示す。この図より, 圧縮強度は水結合材比の増 加とともに減少する傾向がみられる。図一21 は, 圧縮 強度と材令の関係を示したものである。この図より, 結 合材の種類および配合にかかわらず，材令 4 週から 13 週までの圧縮強度の増加がほとんど認められない。しか し, 13 週に扝ける圧縮強度は摚拌 - 貯留しない場合の 強度と大差ないことがわかる。

図一22 および 図一23 は, 曲げ強度と水結合材比およ び材令との関係を示す。水結合材比と曲げ強度の関係は 圧縮強度の場合とほぼ同様であるが，4週から 13 週ま での曲げ強度の伸びは圧縮強度に比べて大きい上うであ

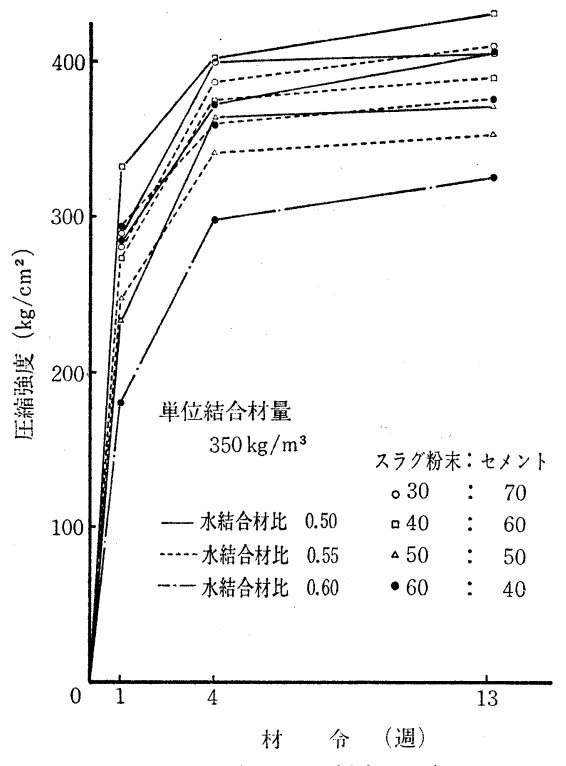

図一21圧縮強度と材令の関係

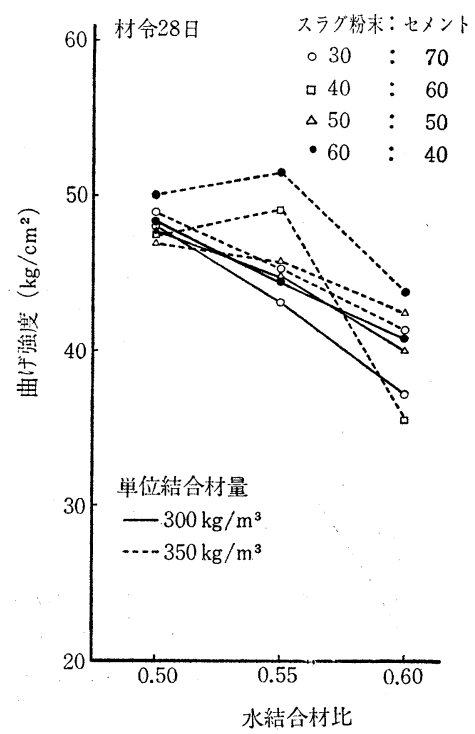

図一22 曲げ強度と水結合材比の関係 
る。曲げ強度圧縮強度比は $1 / 5 \sim 1 / 8$ であり，通常のコ ンクリートと大差ない。

\section{(c) 乾燥収縮試験}

図一24 は，スラグコンクリートにおける乾燥収縮量 の経時変化の一例を示す。この図からわかるように, 収 縮は 4 週まで急速に進行し，8 週ではほぼ完了している ことがわかる。他の配合のスラグコンクリートも同様な 乾燥収縮特性を示すようである。

図一25 は，材令 6 か月におけるスラグコンクリート

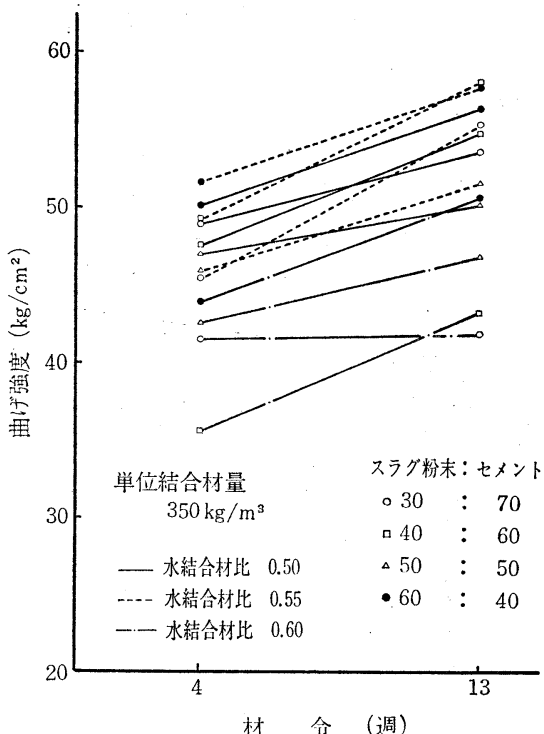

図一23 曲げ強度と材令の関係
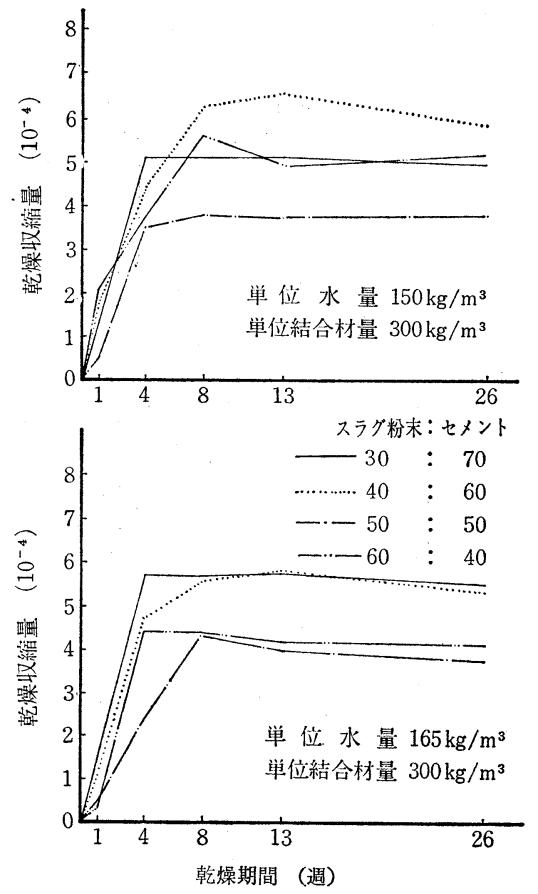

図一24乾燥収縮の経時変化
の収縮量と単位水量の関係を示す。この図より, 乾燥収 縮はほぼ単位水量とともに増大する傾向にあり, 収縮量 は通常のコンクリートと大差ない。

(d) 凍結融解に対する抵抗性

図一26および図一27 は, 各種のスラグコンクリート の動弾性係数比 ( 3 週間水中養生後の凍結融解作用を受 けていない各供試体の動弾性係数を 1 とする）と凍結融 解のサイクル数の関係を示したものである。これらの図 より，スラグコンクリートの凍結融解に対する抵抗性 は，結合材の配合割合にかかわらずかなり大きいことが わかる。これは, 本凍結融解試験に供したスラグコンク リートの水結合材比が比較的小さいこと (50\% および 55 \%）および表一6に示されるように多量のエントラップ

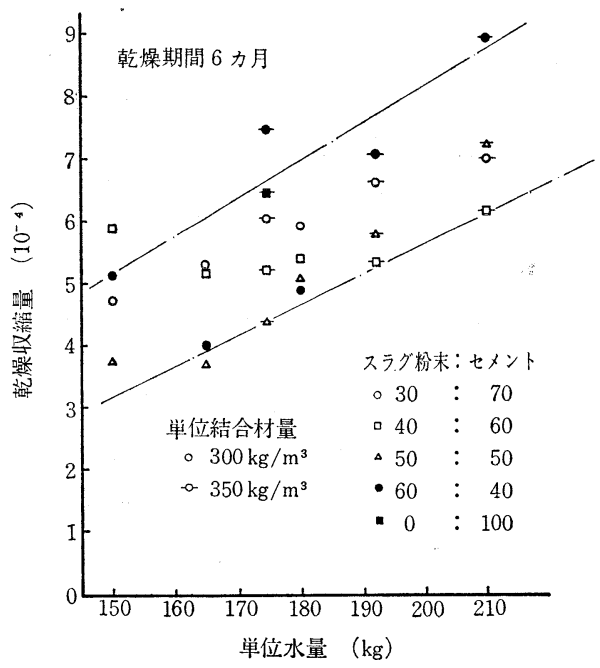

図一25乾燥収縮量と単位水量の関係
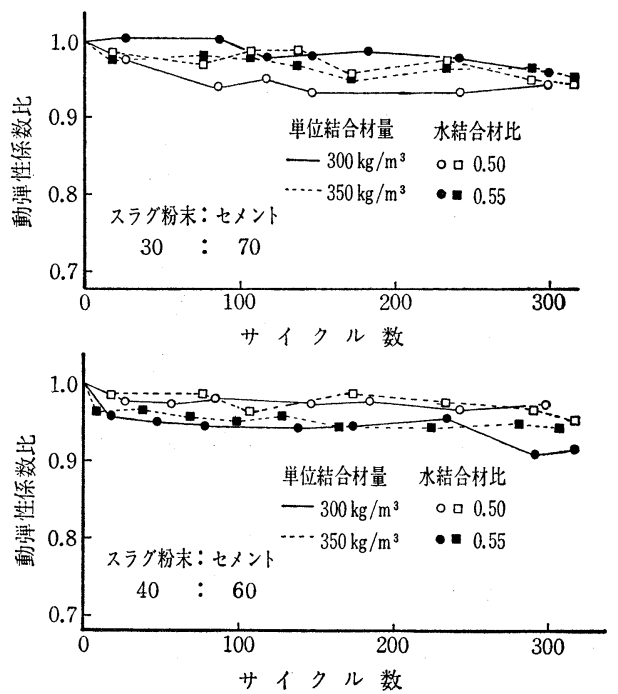

図一26 凍結融解試験における動弾性係数比とサイクル数 の関係 

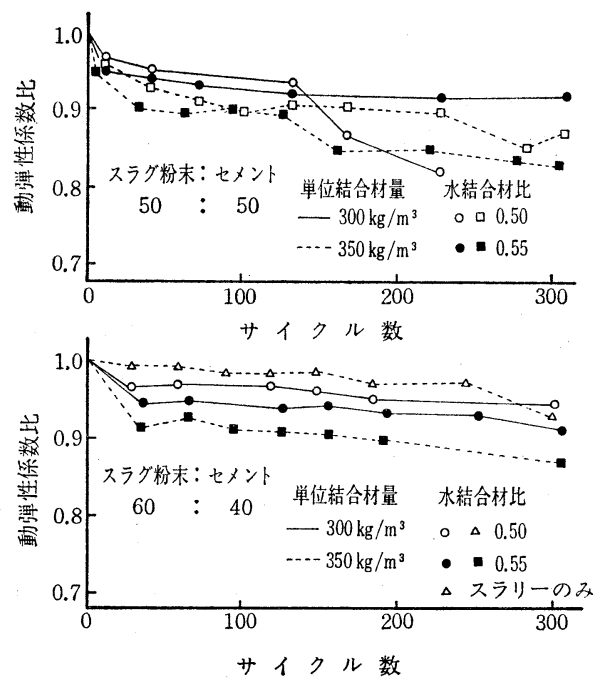

図一27 凍結融解試験における動弾性係数比とサイクル数 の関係

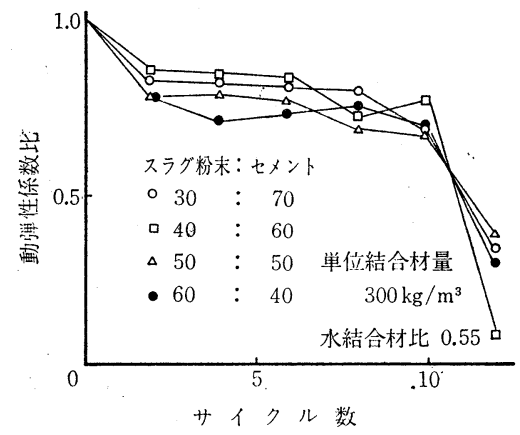

図一28 耐硫酸塩性試験における動弾性係数比と サイクル数の関係

トエアが混入したためと思われる。しかし一般に， $\mathrm{AE}$ 剤を用いないコンクリートの気泡の耐凍結融解性に対す る効果は, $\mathrm{AE}$ 用によって連行される径の小さい気泡に 比べて非常に小さいことが認められている。

各スラグコンクリートの気泡間隔係数 (Spacing Fac(tor) $)^{5)}$ をリニアトラバース法で求めると, 表一7 に示す と㧍りである。この表より明らかなよらに，本実験では $\mathrm{AE}$ 剽を混入していないスラグコンクリートのエントラ ップトエアでむ気泡間隔係数が比較的小さい值を示して いることがわかる。

すなわち，スラリーを擋拌しながら貯留する間に混入 したと考えられる多量のエントラップトエアは, 凍結融 解作用に対する抵抗性の改善に大きく奇与しているよう である。

\section{(e) 而硫酸塩試験}

本実験で採用したアメリカ開拓局の方法では，実験に 供したすべての配合のスラグコンクリートは，基準值以
表一7 気泡間隔係数（S.F.）

\begin{tabular}{|c|c|c|c|}
\hline 結合材の種類し割合 & $\begin{array}{l}\text { 結合材量 } \\
\left(\mathrm{kg} / \mathrm{m}^{3}\right)\end{array}$ & $\begin{array}{l}\text { 水結合材 } \\
\text { 比 }\end{array}$ & S.F. $(\mu \mathrm{m})$ \\
\hline \multirow{2}{*}{$\begin{array}{c}\text { スラグ粉末：セメント } \\
30: 70\end{array}$} & 300 & $\begin{array}{l}0.50 \\
0.55\end{array}$ & - \\
\hline & 350 & $\begin{array}{l}0.50 \\
0.55\end{array}$ & $\begin{array}{l}187 \\
315\end{array}$ \\
\hline \multirow{2}{*}{$40: 60$} & 300 & $\begin{array}{l}0.50 \\
0.55\end{array}$ & $\begin{array}{l}314 \\
232\end{array}$ \\
\hline & 350 & $\begin{array}{l}0.50 \\
0.55\end{array}$ & $\begin{array}{l}133 \\
194\end{array}$ \\
\hline \multirow{2}{*}{$50: 50$} & 300 & $\begin{array}{l}0.50 \\
0.55\end{array}$ & $\begin{array}{l}470 \\
179\end{array}$ \\
\hline & 350 & $\begin{array}{l}0.50 \\
0.55\end{array}$ & $\begin{array}{l}148 \\
291\end{array}$ \\
\hline \multirow[b]{2}{*}{$60: 40$} & 300 & 0.55 & 199 \\
\hline & 350 & $\begin{array}{l}0.50 \\
0.55\end{array}$ & $\begin{array}{l}213 \\
248\end{array}$ \\
\hline $0: 100$ & 350 & 0.55 & 251 \\
\hline
\end{tabular}

下の值（供試体重量の減少が $15 \%$ 以上，膨張が $0.5 \%$ 以上または動弹性係数の減少が $40 \%$ 以上のいずれかに 該当した場合コンクリートは破壊したとする）を示し た。

一般に，スラグ量が多いほど硫酸塩に対する化学的抵 抗性が大きくなると考えられるが，本実験条件の下で は，結合材の混合割合による差は認められなかった。

単位結合材量 $300 \mathrm{~kg} / \mathrm{m}^{3}$, 水結合材比 0.55 の 4 種類 のスラグコンクリートについて, アメリカ開拓局の方法 よりも溶液湛度の高い促進試験 $\left(10 \% \mathrm{Na}_{2} \mathrm{SO}_{4}\right.$ 溶液に 12 時間浸漬, 炉乾燥 12 時間サイクル ${ }^{6)}$ を実施した結 果を示すと図一28 のようである。同図に示されるよう に，高濃度の溶液を使用した場合でも，結合材の混合割 合によって耐硫酸塩性に大差ないことが認められる。

4. 比重計によるスラリーの水セメント比 の推定

排出スラリーの水セメント比を推定する方法として, 塩酸による方法よりも簡単な比重計による方法の適用性 を検討した。採取したスラリーを水で 2 倍に稀䣋したも のの比重測定を行い, 塩酸法によって求めたセメント量 (C) 扔上びセメント水比 $(C / W)$ との関係を求めた結 果を図一29 および 図一30 に示す。これらの図より, スラリーを 2 倍に稀釈することによって比重計によるセ メント量㧍よびセメント水比の推定が问能であることが わかる。 


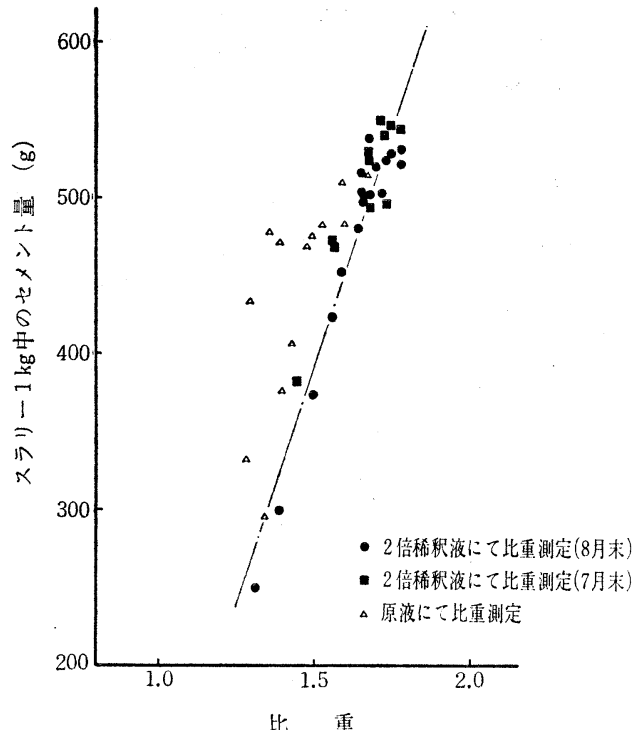

图一29セメントスラリー中の含有セメント量と比重の 関係

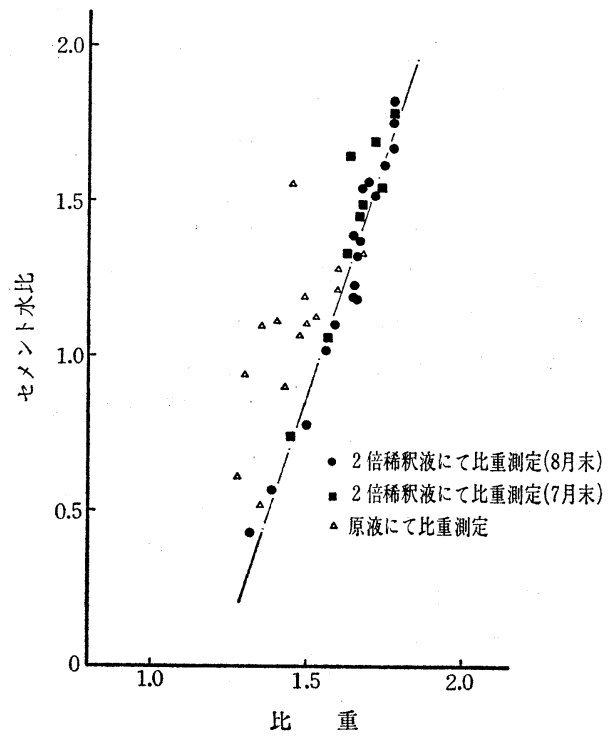

図一30 セメントスラリーのセメント水比と比重の関係
5. 結論

得られた結果を要約すると以下のとおりである。

1） PCくい製造工場から多量に排出するスラリー は，スラグ粉末とともにコンクリートの結合材として再 利用できる。

2）排出スラリーを再利用する場合の問題点である水 セメント比の大きな変動は, スラリーを擋拌しながら一 定時間（90 分以内）貯留することによって小さくでき る。

3）擋拌しながら貯留したスラリーを使用したスラグ コンクリートは，水結合材比が $0.50 \sim 0.60$ の範囲であ れば強度および乾燥収縮は通常のコンクリートとほぼ同 程度であり，耐硫酸塩性扔よび凍結融解に対する抵抗性 は結合材の混合割合にかかわらずかなり大きい。

\section{参考文 献}

1）神田 衛：まだ固まらないコンクリートの水セメント比 の測定方法, 土木学会コンクリートライブラリー, No. 38 , pp. $43 \sim 54,1974$

2) 日本材料学会編：建設材料実験

3）魚本健人, 小林一輔, 星野富夫 : 高炉水砕スラグーセッコ ウ系結合材を用いたコンクリートに関する基礎的研究 (2), 生産研究, Vol. 30 , No. 10, pp. 379 382, 1978

4）魚本健人, 小林一輔, 星野富夫：高炉水砕スラグーセッ コウ系結合材を用いたコンクリートの圧縮強度特性, 第 1 回コンクリート工学年次講演会講演論文集, pp. 117 120,1979

5) T.C. Powers : Void Spacing as a Basis for Producing Air-Entrained Concrete, ACI Journal, Vol. 50, No. 5,1954

6）西林新蔵, 阪田憲次：コンクリートの而硫際塩性促進試 験に関する研究, 土木学会論文報告集, No. 207, pp. 83 $\sim 91,1972$

（原稿受理年月日：昭和 56 年 8 月 31 日） 